\title{
Hubungan Kerasionalan Peresepan Obat Antihipertensi Dengan Outcome Klinis Pada Pasien Stroke Iskemik Rawat Inap RSUD Dr. Soegiri Lamongan
}

\section{The Rational Relationship of Prescribing Antihypertensive Drugs and Clinical Outcomes in Ischemic Stroke Patients inpatients at Dr. Soegiri Hospital Lamongan}

\author{
Muhammad Muhlis*, Luthfiyya Iffa Muslimah \\ Departemen Farmasi Klinik dan Sosial, Fakultas Farmasi Universitas Ahmad Dahlan \\ Jl. Prof. Dr. Soepomo, Janturan, Yogyakarta 55164, Indonesia \\ *E-mail : muhammad.muhlis@pharm.uad.ac.id
}

Received: 7 Januari 2021; Accepted: 17 Juni 2021; Published: 30 Juni 2021

\begin{abstract}
Abstrak
Stroke Iskemik merupakan gangguan suplai darah ke otak yang disebabkan oleh sumbatan pembuluh darah. Hipertensi merupakan penyakit penyerta pada kejadian stroke iskemik. Pengobatan yang tepat dapat mempengaruhi keberhasilan terapi dan pencapaian tekanan darah yang diinginkan. Penelitian ini bertujuan untuk mengevaluasi kerasionalan penggunaan obat antihipertensi terhadap pencapaian outcome klinis yang berupa tekanan darah. Penelitian ini dirancang secara observasional analitik dengan pendekatan cross sectional, bersifat retrospektif dengan metode purposive sampling pada pasien stroke iskemik yang menerima resep antihipertensi di rawat inap RSUD Dr. Soegiri Lamongan. Sampel yang digunakan 100 pasien. Hasil penelitian didapatkan bahwa golongan obat antihipertensi yang banyak digunakan yakni CCB dengan persentase 41,8\%, ARB dengan persentase 27,6\%. Kerasionalan peresepan didapat: tepat indikasi $100 \%$, tepat pasien $100 \%$, tepat obat $91 \%$ dan tepat dosis $100 \%$. Hasil uji Chi Square didapatkan nilai expected $<5$ sehingga dilanjutkan dengan uji Fisher's Test diperoleh nilai p 0,021 ( $<<0,05)$. Kesimpulan dari penelitian ini adalah pasien yang menerima resep antihipertensi yang rasional sebanyak $91 \%$, untuk pasien yang mencapai outcome klinis sebanyak $86 \%$ dan terdapat hubungan antara kerasionalan peresepan obat antihipertensi dengan outcome klinis berupa tercapainya target tekanan darah pada pasien stroke iskemik di RSUD Dr. Soegiri Lamongan.

Kata kunci : Stroke iskemik, Kerasionalan resep antihipertensi, Outcome Klinis
\end{abstract}

\begin{abstract}
Ischemic stroke is a disruption of blood supply to the brain caused by the blockage of blood vessels. Hypertension is a comorbid disease in ischemic stroke. Appropriate treatment can affect the success of therapy and the achievement of the desired blood pressure. This study aims to evaluate the rationale for using antihypertensive drugs to achieve clinical outcomes in the form of blood pressure. This study was designed in an observational analytic manner with a cross-sectional approach, retrospective in nature with a purposive sampling method in ischemic stroke patients who received antihypertensive prescriptions in RSUD Dr. Soegiri Lamongan. The sample used was 100 patients. The results showed that the most widely used antihypertensive drugs were CCB with a percentage of $41.8 \%$, ARB with a percentage of $27.6 \%$. The rationale for prescribing was obtained: $100 \%$ correct indication, $100 \%$ correct patient, $91 \%$ correct drug, and 100\% correct dose. The results of the Chi-Square test have obtained an expected value of $<5$, so that it is followed by the Fisher's Test, which obtained a p-value of 0.021 ( $p<0.05$ ). The conclusion of this study is that patients who received a rational antihypertensive prescription were $91 \%$, for patients who achieved clinical outcomes as much as $86 \%$ and there was a relationship between the rationality of prescribing antihypertensive drugs with clinical outcomes in the form of achieving target blood pressure in ischemic stroke patients at RSUD Dr. Soegiri Lamongan.
\end{abstract}

Keywords: Ischemic stroke, Rationality of antihypertensive prescriptions, Clinical Outco 


\section{PENDAHULUAN}

Stroke secara klasik ditandai sebagai defisit neurologis yang dikaitkan dengan cedera fokal akut pada sistem saraf pusat (SSP) oleh penyebab vaskular, termasuk infark serebral, Intracerebral hemorrhage (ICH), dan perdarahan subarachnoid (SAH), dan merupakan penyebab utama dari cacat dan kematian di seluruh dunia.(Sacco et al., 2013)

Stroke menjadi penyakit yang membahayakan dan sudah menjadi penyakit penyebab kematian kedua di dunia dan mejadi penyebab kematian ketiga di Amerika Serikat, setelah penyakit kardiovaskular dan kanker (Ivanov et al., 2015). Di Indonesia, penyakit ini merupakan salah satu penyebab kematian dan kecacatan neurologis yang tertinggi. Diperkirakan setiap tahun 500.000 penduduk yang terkena serangan stroke, ada sekitar $2,5 \%$ atau 125.000 orang yang meninggal, selebihnya mengalami cacat ringan maupun berat (Riyadina dan Rahajeng, 2013).

Kejadian penyakit stroke meningkat sehubungan dengan bertambahnya usia, prevalensi tertinggi pada umur di atas 75 tahun (Kemenkes RI, 2013). Sekitar 70-94\% pasien stroke akut diikuti peningkatan tekanan darah sistolik >140 mmHg. Dari hasil penelitian di Indonesia ditemukan kejadian hipertensi pada pasien stroke akut sekitar $73,9 \%$ dan sebesar $22,5-27,6 \%$ di antaranya mengalami kenaikan tekanan darah sistolik diatas $180 \mathrm{mmHg}$ (PERDOSSI, 2011).

Hipertensi merupakan faktor risiko utama pada kejadian stroke yang dapat dikendalikan dengan pemberian terapi antihipertensi yang tepat. Penyakit hipertensi dapat meningkatkan sebanyak 6 kali lebih besar resiko terjadinya stroke. Pasien dikatakan hipertensi jika tekanan darah lebih dari 140/90 mmHg, jika tekanan darah semakin tinggi maka resiko kemungkinan stroke akan semakin besar disebabkan terjadinya kerusakan dinding pembuluh darah yang dapat menyebabkan terjadi penyumbatan bahkan pecahnya pembuluh darah di otak (Junaidi, 2011). Terapi antihipertensi pada pasien yang sudah mengalami stroke merupakan terapi sekunder untuk pencegahan terjadinya serangan stroke berulang, risiko hemoragik dan untuk mencegah kerusakan vaskular lebih lanjut (Muir and Keith, 2013).

Penatalaksanaan hipertensi yang tepat pada stroke iskemik sangat mempengaruhi morbiditas dan mortilitas stroke. Terapi dengan target penurunan darah berpengaruh pada penurunan kejadian stroke berulang. Pemberian terapi pencegahan sekunder secara optimal dapat mencegah terjadinya stroke berulang sebesar $80 \%$ (Prabhakaran dan Chong, 2014). Penanganan hipertensi pada pasien stroke iskemik diharapkan dapat meningkatkan atau memperbaiki outcome klinis pada pasien, dengan menangani peningkatan tekanan darah pada kondisi akut diharapkan kerusakan yang terjadi pada sistem syaraf akan menjadi seminimal mungkin dan tidak terjadi komplikasi yang membahayakan jiwa pasien seperti terjadinya perdarahan pada pembuluh darah yang tersumbat (Sedjatiningsih, 2012).

RSUD Dr. Soegiri adalah salah satu rumah sakit di Kabupaten Lamongan, penderita penyakit stroke iskemik menjadi urutan kedua dari 10 penyakit terbesar pada tahun 2018 dan belum ada penelitian mengenai rasionalitas penggunaan obat antihipertensi pada pasien stroke iskemik di rawat inap RSUD Dr. Soegiri Lamongan. Untuk itu perlu dilakukan penelitian untuk menganalisis kerasionalan peresepan obat antihipertensi dibandingkan dengan outcome klinis pada pasien stroke iskemik rawat inap RSUD Dr. Soegiri Lamongan.

\section{METODE PENELITIAN}

Penelitian ini merupakan penelitian observasional analitik dengan pendekatan 
cross sectional yang bersifat retrospektif. Data penggunaan obat yang diperoleh dari rekam medis periode Januari-Desember 2018 tersebut kemudian dianalisis kerasionalannya yang meliputi (tepat pasien, tepat indikasi, tepat obat, tepat dosis) dan dihubungan dengan outcome klinis yang berupa tekanan darah. Kriteria yang digunakan dalam menilai kerasionalan meliputi tepat indikasi, tepat pasien, tepat obat dan tepat dosis.

Dikatakan tepat pasien jika obat yang diberikan tidak menimbulkan alergi dan tidak dikontraindikasikan kepada pasien, dikatakan tepat indikasi jika pasien memperoleh obat sesuai dengan diagnosis dokter yaitu pasien yang terdiagnosa stroke iskemik dengan hipertensi. Penilaian tepat obat jika obat yang diberikan tidak terjadi interaksi satu dengan lainnya dilihat dari aplikasi Medscape pada bagian Drug Interaction Checker dan sesuai standar terapi, dikatakan tepat dosis jika dosis sesuai dengan rute pemberian, frekuensi penggunaan obat sesuai dengan rentang dosis berdasarkan standar terapi. Dikatakan rasional jika keempat kriteria tepat terpenuhi, dikatakan tidak rasional jika ada salah satu kriteria tepat yang tidak terpenuhi. Outcome klinis pada penelitian ini adalah tekanan darah pasien. Pengukuran tekanan darah sistolik dan diastolik (mmHg) dilihat pada hari terakhir sebelum pasien keluar dari rumah sakit. Pada kelompok obat antihipertensi yang digunakan pasien di rumah sakit dianalisis menggunakan statistik Fisher's exact test apakah bermakna atau tidak secara statistik ( $\mathrm{p}$ value $<0,05)$ dan dilihat apakah sudah mencapai target yang diharapkan sesuai guideline JNC $8<140 / 90$ $\mathrm{mmHg}$.

\section{HASIL DAN PEMBAHASAN}

Penelitian ini dilakukan pada pasien stroke iskemik yang mendapat terapi obat antihipertensi di rawat inap RSUD Dr. Soegiri Lamongan dan telah memperoleh persetujuan melalui etichal clearance yang disetujui oleh komisi etik Universitas Gadjah Mada dengan nomor ref : KE/FK/0611/EC/2019. Penelitian ini yang dilaksanakan pada 14--26 Juni 2019. Sampel yang digunakan adalah sampel yang memenuhi kriteria inklusi berupa pasien yang didiagnosa stroke iskemik dengan hipertensi oleh (DPJP - baik dokter spesialis atau dokter umum) dan menerima terapi obat antihipertensi selama pengobatan rawat inap di RSUD Dr. Soegiri Lamongan periode Januari-Desember 2018, data rekam medis lengkap dan mudah dibaca, pasien menerima pemeriksaan tekanan darah dari hari pertama masuk rawat inap- hari terakhir. Sedangkan kriteria eksklusinya adalah pasien stroke iskemik dengan hipertensi yang hamil dan meninggal di instalasi rawat inap RSUD Dr. Soegiri Lamongan periode Januari-Desember 2018.

Jumlah pasien yang digunakan sebagai sampel penelitian berdasarkan rumus lemeshow sebagai berikut :

$$
n=\frac{Z^{2}-\propto / P(1-P)}{d^{2}}
$$

Diperoleh n sebesar 96 sampel dan dibulatkan menjadi 100 sampel

\section{Karakteristik Demografi Pasien}

Karakteristik demografi pasien dalam penelitian ini meliputi umur, jenis kelamin, pendidikan, pekerjaan (Tabel 1.)

Hasil penelitian menunjukkan bahwa bahwa penderita stroke iskemik didominasi oleh pasien perempuan (52\%) hal ini mungkin terjadi karena perempuan mengalami menopause terjadi perubahan hormonal yaitu penurunan perbandingan estrogen dan androgen yang menyebabkan peningkatan pelepasan renin, sehingga dapat memicu peningkatan tekanan darah (Coylewright et al., 2008). Hal ini sesuai dengan penelitian Rossum et al. (2000) bahwa perempuan berisiko lebih tinggi mengidap hipertensi 
dibandingkan dengan laki-laki.

Penderita stroke iskemik lebih banyak pada kelompok umur di atas 55 tahun (72\%). Ariesta (2012) dalam penelitiannya menyatakan bahwa pasien stroke terbanyak terjadi pada usia 55 tahun hingga 64 tahun yang sebagian besar disebabkan akibat hipertensi (Ramadhini dkk, 2013). Risiko yang dimiliki oleh seseorang untuk menderita stroke bertambah dua kali lipat setelah usia 55 tahun, kejadian ini lebih sering terjadi pada pasien yang berusia lebih tua disebabkan karena keadaan ini merupakan penyakit yang terjadi akibat gangguan aliran pembuluh darah. Pembuluh darah pada manula cenderung mengalami perubahan secara degeneratif dan mulai terlihat dari proses aterosklerosis (Goldstein et al, 2011).

\section{Profil penggunaan obat Antihipertensi}

Dapat dilihat dari tabel 1 bahwa penggunaan obat antihipertensi pasien stroke iskemik dengan hipertensi dikelompokkan berdasarkan pemberian tunggal dan kombinasi serta jenis obat yang diterima. Pada pasien stroke iskemik dengan hipertensi dapat menggunakan semua jenis golongan antihipertensi dengan dilakukan penyesuaian terhadap kondisi akut dan fisiologis masing-masing pasien untuk mencegah secondary prevention stroke (PERDOSSI, 2011).

Pemberian terapi antihipertensi kombinasi diberikan ketika tekanan darah tidak dapat dikontrol dengan terapi tunggal stategi pemberian ini dapatmengurangi terjadinya efek samping (Naidu et al., 2000). Selain itu terapi kombinasi disarankan untuk diberikan pada berbagai kondisi pasien stroke misalnya hasil terapi pasien yang jauh dari target yang diinginkan, pasien yang sulit mencapai target pada pemberian tunggal dan pasien yang memiliki beberapa komplikasi (Saseen dan Maclaughlin, 2008).

Kombinasi antihipertensi dari golongan yang berbeda dimaksudkan untuk meningkatkan efikasi yang disebabkan efek sinergis pada dosis yang lebih rendah, dengan demikian dapat meminimalkan efek samping obat (Aronow et al., 2011; Kalra et al., 2010). Menurut JNC VIII, apabila tekanan darah $>20 / 10 \mathrm{mmHg}$ di atas target penurunan tekanan darah yaitu $<140 / 90 \mathrm{mmHg}$ atau $<130 / 80 \mathrm{mmHg}$ pada pasien hipertensi dengan diabetes melitus atau penyakit gangguan ginjal, maka dapat diberikan terapi kombinasi .

Kombinasi obat antihipertensi yang paling sering digunakan pada penelitian ini adalah golongan CCB dan ARB yaitu sebesar 25\%. Kombinasi ini direkomendasikan oleh ESH/ESC (European Society of Hypertension/European Society of Cardiology) sebagai pilihan pertama pada pasien hipertensi dengan stroke (Ravenni, 2011). Kombinasi ini dapat menurunkan efek induksi golongan CCB terhadap edema perifer (LingWu et al., 2014).

Kombinasi terbanyak antihipertensi lain yang diberikan adalah golongan $\mathrm{CCB}$ dengan ACEI. Kombinasi ini lebih efektif menurunkan tekanan darah baik sistolik maupun diastolik (Kalra et al., 2012). Kombinasi ini memiliki kelebihan berupa menurunnya risiko progresifitas penyakit menjadi semakin memburuk. Selain itu kombinasi ini dapat diberikan pada dosis yang lebih rendah disebabkan karena kedua obat memiliki efek saling menguatkan (aditif), sehingga kombinasi ini dapat menurunkan risiko terjadinya efek samping dari kedua golongan ini. CCB golongan dihidropiridin dapat menyebabkan hidrolisis sehingga tubuh kehilangan air dan natrium efek ini menyebabkan tubuh memberikan respon berupa mengaktifkan sistym renin angiotensin II dalam sirkulasi darah. Kejadian ini merupakan efek respon tubuh untuk mengimbangi efek penurunan 
tekanan darah oleh golongan CCB Kombinasi ini akan mengurangi peningkatan angiotensin II dalam darah dan selanjutnya akan membuat efek farmakologis dari golongan CCB semakin efektif (LingWu et al., 2014).

Kombinasi kedua golongan ini juga dapat menghambat terjadinya agregasi platelet. Golongan CCB dapat menghambat terjadinya agregasi platelet disebabkan secara fisiologis angiotensin II menginduksi aktivasi platelet. Golongan ACEI menghambat terbentuknya angiotensin II sehingga kejadian ini dapat memberikan efek antiplatelet (Naidu, 2000).

Menurut guideline AHA (2018) direkomendasikan beberapa obat antihipertensi pada stroke iskemik seperti alfa-adrenoreseptor antagonis, ACEI, ARB, beta-adrenoreseptor antagonis, $\mathrm{CCB}$, diuretik. Obat antihipertensi lain yang direkomendasikan $\mathrm{CCB}$, tiazid, ACEI, beta-blocker, alfa-blocker, dan vasodilator langsung (PERDOSSI, 2011). Rekomendasi obat antihipertensi untuk pasien stroke adalah alfa-2-adrenoreseptor agonis, ACEI, ARB, BB, CCB dan diuretik (Appleton et al., 2016).

Guideline The European Society of Hypertention (ESH) and European of Cardiology (ESC) tahun 2013 merekomendasikan antihipertensi pada pasien hipertensi dengan stroke untuk mencegah stroke berulang (secondary prevention) dengan pilihan obat ACEI, $\mathrm{ARB}, \mathrm{CCB}$ atau diuretik sebagai tunggal atau kombinasi 2 atau 3. Berdasarkan hal tersebut, pemilihan golongan obat antihipertensi untuk pasien stroke iskemik rawat inap di RSUD Dr. Soegiri Lamongan sudah sesuai dengan guideline yang ada.

Obat amlodipin golongan CCB paling banyak digunakan baik secara monoterapi maupun kombinasi. Golongan antihipertesi lain yang diberikan baik monoterapi maupun kombinasi terbanyak setelah CCB adalah ARB dan ACEI. Hal ini sesuai dengan penelitian Rumah Sakit Stroke Iskemik Bukittinggi bahwa golongan obat penghambat kalsium adalah golongan obat antihipertensi yang paling sering diberikan kepada pasien stroke iskemik baik sebagai monoterapi maupun kombinasi terapi melalui rute per oral (Juwita et al., 2017). Penelitian serupa selanjutnya dilakukan di RSUD Dr. Soetomo Surabaya pada tahun 2015 bahwa antihipertensi terbanyak adalah golongan CCB yakni amlodipin (Kurniawati, 2015). Pasien dengan ratarata usia di atas 55 tahun pilihan pertama untuk terapi antihipertensinya adalah golongan CCB (Gormer, 2010). Golongan CCB memiliki banyak kelebihan hal ini dikarenakan golongan CCB terutama untuk kelas dihidropiridin banyak digunakan untuk mengendalikan tekanan darah pasien yang tidak terkontrol jika menggunakan golongan ACEI ataupun ARB, disebabkan golongan CCB dihidropiridin dapat menurunkan tekanan darah dalam waktu yang singkat. Selain itu pada penelitian lain menyebutkan bahwa golongan $\mathrm{CCB}$ dapat menurunkan risiko penyakit kardiovaskular dan stroke (Aronow et al., 2011; Kalra et al., 2010). 
Tabel 1. Karakteristik pasien stroke skemik yang mendapat terapi obat antihipertensi di rawat inap RSUD Dr. Soegiri Lamongan dan golongan obat hipertensi

\begin{tabular}{|c|c|c|c|c|}
\hline Karekteristik & & Keterangan & Jumlah $(\mathrm{n}=100)$ & $\%$ \\
\hline \multirow[t]{2}{*}{ Jenis Kelamin } & & Laki-laki & 48 & 48,0 \\
\hline & & Perempuan & 52 & 52,0 \\
\hline \multirow{2}{*}{\multicolumn{2}{|c|}{ Umur }} & Kurang 55 tahun & 28 & 28,0 \\
\hline & & Diatas 55 tahun & 72 & 72,0 \\
\hline \multirow{5}{*}{\multicolumn{2}{|c|}{ Pendidikan }} & Perguruan Tinggi & 8 & 8,0 \\
\hline & & SLTA & 14 & 14,0 \\
\hline & & SLTP & 12 & 12,0 \\
\hline & & $\mathrm{SD}$ & 48 & 48,0 \\
\hline & & Tidak Sekolah & 18 & 18,0 \\
\hline \multirow{7}{*}{\multicolumn{2}{|c|}{ Pekerjaan }} & PNS & 12 & 12,0 \\
\hline & & Wiraswasta & 22 & 22,0 \\
\hline & & Pedagang & 2 & 2,0 \\
\hline & & Petani & 28 & 28,0 \\
\hline & & Buruh & 5 & 5,0 \\
\hline & & Pensiun & 2 & 2,0 \\
\hline & & Tidak Bekerja & 29 & 29,0 \\
\hline \multirow{16}{*}{$\begin{array}{l}\text { Golongan } \\
\text { hipertensi }\end{array}$} & Obat & $\mathrm{CCB}$ & 20 & 20,0 \\
\hline & & ARB & 8 & 8,0 \\
\hline & & $\mathrm{BB}$ & 2 & 2,0 \\
\hline & & ACEI & 2 & 2,0 \\
\hline & & $\mathrm{CCB}+\mathrm{ARB}$ & 25 & 25,0 \\
\hline & & $\mathrm{CCB}+\mathrm{ACEI}$ & 14 & 14,0 \\
\hline & & $\mathrm{CCB}+$ Diuretik & 2 & 2,0 \\
\hline & & $\mathrm{CCB}+\mathrm{BB}$ & 1 & 1,0 \\
\hline & & $\mathrm{ARB}+\mathrm{BB}$ & 1 & 1,0 \\
\hline & & ARB + Diuretik & 5 & 5,0 \\
\hline & & Diuretik + BB & 1 & 1,0 \\
\hline & & $\mathrm{CCB}+\mathrm{ARB}+\mathrm{ACEI}$ & 9 & 9,0 \\
\hline & & $\mathrm{CCB}+\mathrm{ARB}+\mathrm{BB}$ & 4 & 4,0 \\
\hline & & $\mathrm{CCB}+\mathrm{ARB}+$ Diuretik & 3 & 3,0 \\
\hline & & $\mathrm{CCB}+\mathrm{BB}+\mathrm{ACEI}$ & 2 & 2,0 \\
\hline & & $\begin{array}{l}\mathrm{CCB}+\mathrm{ACEI}+ \\
\text { Diuretik }\end{array}$ & 1 & 1,0 \\
\hline
\end{tabular}

Obat golongan ARB yang digunakan adalah candesartan, obat ini dapat menurunkan risiko stroke berulang lebih besar daripada menggunakan diuretik, CCB dihidropiridin, ACEI dan BB dengan penurunan tekanan darah yang relatif sama
(Revenni, 2011). Obat golongan ARB digunakan karena mempunyai efek samping paling rendah dibandingkan dengan obat antihipertensi lain (Kemenkes RI, 2006). Manfaat ARB dalam penurunan tekanan darah, kardiovaskular dan pencegahan 
stroke berulang dengan selektif memblok angiotensin II pada reseptor tipe I (Zhang et al., 2011).

Obat golongan ACEI yang digunakan adalah Lisinopril. Penelitian yang ada menunjukkan bahwa pemberian ACEI pada hari ke 2-4 setelah stroke aman pada pasien dengan stroke ringan atau TIA tanpa penyakit karotis (Nazir FS, 2005). ACEI tidak hanya berfungsi untuk menurunkan tekanan darah namun juga berguna bagi pasien dengan penyakit jantung koroner. ACEI diduga memiliki efek protektif terhadap pembuluh darah selain dari efek antihipertensinya sendiri. ACEI tidak mempengaruhi autoregulasi otak dan memperbaiki keadaan endothelial, tidak seperti obat antihipertensi golongan lainnya (Rashid, 2003). Namun penggunaan ACEI dapat mengakibatkan efek samping berupa batuk, hipotensi postural, hiponatremia. Pada pasien yang tidak dapat mengkonsumsi ACEI dapat digantikan dengan ARB tanpa efek samping tambahan (Hankey GJ, 2003).

Obat antihipertensi dari golongan diuretik yang digunakan adalah furosemide. Furosemide termasuk loop diuretik digunakan untuk pasien hipertensi dengan mekanisme kerja dengan cara menurunkan volume darah sehingga menurunkan tekanan pada vena dan kapiler hidrostatik dan berfungsi untuk mengurangi cairan (Juan et al., 2014). Furosemide terbukti menurunkan kejadian stroke berulang, cedera vaskular dan mencegah komplikasi kardiovaskular dari hipertensi (Allahat, 2002). Diuretik lain yang diberikan adalah spironolakton dan hidroklortiazid. Spironolakton merupakan diuretik hemat kalium yang dapat menggantikan kalium yang hilang akibat diuretik lain (Kemenkes RI, 2006). Diuretik tiazid seperti hidroklortiazid direkomendasikan JNC 7 untuk pencegahan stroke berulang. JNC 8 merekomendasikan penggunaan diuretik untuk pencegahan stroke berulang.

Golongan $\beta$ blocker merupakan obat antihipertensi yang sering diresepkan untuk pasien yang meiliki penyakit kardiovaskular. $\beta$ blocker tidak boleh dijadikan lini pertama untuk pasien hipertensi tanpa komplikasi (Dinicolantonio et al., 2015). $\beta$-blocker direkomendasikan sebagai lini kedua setelah RAAS untuk mengendalikan hipertensi pada pasien dengan CKD dan gagal jantung (Tomiyama dan Yamashina, 2014). Golongan $\beta$ blocker memiliki 2 jenis sifat farmakologi yang terdiri dari $\beta 1$ dan $\beta 2 . \beta 1$ lebih banyak digunakan karena kerjanya selektif dengan menghambat reseptor $\beta 1$ di jantung sedangkan $\beta 2$ bekerja secara non selektif dengan cara mengambat reseptor $\beta 1$, $\beta 2$ (postsinaptik dan presinaptik) dan $\alpha 1$ (Dinicolantonio et al., 2015). Pada tabel VII menunjukkan bahwa penggunaan $\beta$ blocker yang sering digunakan yaitu bisoprolol. Penggunaan bisoprolol terbukti lebih efektif dalam mempertahankan penurunan tekanan darah dibandingkan dengan atenolol sehingga bermanfaat untuk mempertahankan tekanan darah yang tekontrol (Tomiyama dan Yamashina, 2014).

\section{Evaluasi Ketepatan Terapi}

Pemberian obat antihipertensi yang rasional pada pasien stroke iskemik dengan hipertensi merupakan hal yang sangat penting agar tujuan terapi dapat tercapai. Pada penelitian ini dilakukan evaluasi pengggunaan obat antihipertensi pada pasien stroke iskemik di rawat inap RSUD Dr. Soegiri Lamongan periode 2018 yang meliputi empat kriteria yaitu tepat pasien, tepat indikasi, tepat obat dan tepat dosis. 
Pengobatan dikatan rasional jika keempat kriteria telah terpenuhi, tetapi jika ada salah satu kriteria yang tidak terpenuhi maka pengobatan tersebut dianggap tidak rasional.

Tabel 2. Evaluasi rasionalitas peresepan obat antihipertensi pada pasien stroke iskemik rawat inap RSUD Dr. Soegiri Lamongan

\begin{tabular}{lllll}
\hline Kriteria & Tepat & $\mathbf{\%}$ & TidakTepat & \% \\
\hline Tepat Indikasi & 100 & $100 \%$ & 0 pasien & $0 \%$ \\
Tepat Pasien & 100 & $100 \%$ & 0 pasien & $0 \%$ \\
Tepat Obat & 91 & $91 \%$ & 9 pasien & $9 \%$ \\
Tepat Dosis & 100 & $100 \%$ & 0 pasien & $0 \%$ \\
\hline
\end{tabular}

\section{Tepat Indikasi}

Ketepatan indikasi diartikan bahwa setiap obat memiliki spektrum terapi yang spesifik yang dalam hal ini adalah antihipertensi yang diindikasikan untuk hipertensi. Dengan demikian pemberikan obat ini hanya dianjurkan untuk pasien yang memiliki tekanan darah yang tinggi (Kemenkes RI, 2011). Tepat indikasi juga diartikan bahwa ketepatan pemberian obat yang disesuaikan dengan diagnosis yang tercantum dalam rekam medik pasien stroke iskemik dengan hipertensi RSUD Dr. Soegiri Lamongan.

Hasil penelitian pada Tabel 2 menunjukan bahwa penggunaan obat antihipertensi yang sudah sesuai dengan diagnosis sebanyak 100 pasien dengan persentase $100 \%$.

Hal ini sesuai dengan penelitian sebelumnya yang dilakukan Juwita et al. (2017). Penelitian tersebut mengenai evaluasi penggunaan obat antihipertensi pada pasien stroke iskemi di RSSN Bukittinggi menunjukkan $100 \%$ tepat indikasi yang artinya pemberian antihipertensi pada pasien stroke iskemik ini telah sesuai dengan indikasi yang seharusnya menurut standar yang telah ditetapkan.

\section{Tepat Pasien}

Ketepatan pasien diartikan bahwa respon individu terhadap efek obat sangat beragam. Obat yang diberikan harus benarbenar efektif dan aman dengan mutu yang terjamin serta tersedia setiap saat pada pasien yang telah didagnosa sebelumnya (Kemenkes RI, 2011).

Ketepatan pasien juga diartikan bahwa ketetapan pemilihan obat yang mempertimbangkan keadaan pasien sehingga tidak menimbulkan kontraindikasi. Evaluasi ketepatan pasien pada penggunaan antihipertensi dilakukan dengan kondisi pasien pada data rekam medis (Sumawa, 2015).

Hasil penelitian yang disajikan pada Tabel 2 menunjukan bahwa penggunaan obat antihipertensi pada pasien stroke iskemik dengan hipertensi yang sesuai sebanyak 100 pasien dengan persentase 100\%. Sehingga dapat dikatakan penggunaan obat antihipertensi sudah tepat pasien tidak ada obat yang di kontraindikasikan dengan konsisi pasien. Hal ini sesuai dengan penelitian sebelumnya yang dilakukan oleh Juwita et al. (2017) yaitu penelitian mengenai evaluasi penggunaan obat antihipertensi pada pasien 
stroke iskemi di RSSN Bukittinggi menunjukkan semua pasien stroke iskemik dengan penyakit penyerta hipertensi sudah mendapatkan obat antihipertensi yang tepat dan telah sesuai dengan golongan obat yang direkomendasikan, artinya semua terapi yang diberikan sudah $100 \%$ tepat pasien.

\section{Tepat Obat}

Ketepatan pemilihan obat merupakan keputusan untuk melakukan upaya terapi yang diambil setelah diagnosis ditegakkan dengan benar dengan demikian, obat yang dipilih harus yang memili efek terapi sesuai dengan spektrum penyakit (Kemenkes RI, 2011). Hal ini menunjukkan bahwa pemilihan obat harus benar-benar berdasarkan jenis penyakit yang telah didiagnosa secara medis.

Evaluasi ketepatan obat dilihat dari ketepatan jenis pengobatan antihipertensi yang diberikan dengan diagnosis yang tertulis di rekam medik RSUD Dr. Soegiri Lamongan dibandingkan dengan drug of choice pasien stroke iskemik dengan hipertensi serta ada tidaknya interaksi antara obat antihipertensi satu dengan yang lainnya dilihat dari aplikasi medscape pada bagian drug interaction checker.

Pasien stroke iskemik dengan hipertensi menunjukkan bahwa $91 \%$ pasien sudah tepat obat sedangkan terdapat $9 \%$ pasien tidak tepat obat karena terjadinya interaksi antara obat antihipertensi satu dengan lainnya. Dari 9\% pasien yang mengalami kejadian interaksi obat yang serius pada penggunaan antihipertensi kombinasi candesartan dengan lisinopril yang dapat meningkatkan risiko hipotensi, hiperkalemia dan gangguan ginjal pada pasien sehingga sebaiknya dihindari.

\section{Tepat Dosis}

Ketepatan dosis diartikan bahwa dosis, cara dan lama pemberian obat sangat berpengaruh terhadap efek terapi obat. Pemberian dosis yang berlebihan, khususnya untuk obat dengan rentang terapi yang sempit akan sangat berisiko timbulnya efek samping. Sebaliknya dosis yang terlalu kecil tidak akan menjamin tercapainya kadar terapi yang diharapkan (Kemenkes RI, 2011).

Berdasarkan Tabel 3, diketahui bahwa RSUD Dr. Soegiri Lamongan memberikan obat antihipertensi kepada 100 pasien yang telah memiliki kategori tepat indikasi. Dari 100 pasien tersebut diketahui memiliki ketepatan dosis sebesar $100 \%$ pada semua jenis obat sesuai dengan dosis antihipertensi yang direkomendasikan oleh Drug Information Handbook.

Semua terapi yang diberikan sudah $100 \%$ tepat pasien. Sesuai dengan patologi dan fisiologi pasien serta tidak menimbulkan kontraindikasi pada pasien.

Ketepatan pemberian obat atau dinyatakan pemberian terapi tersebut rasionalitas apabila memenuhi empat kriteria (4T) dari terapi antihipertensi yang meliputi tepat indikasi, tepat pasien, tepat obat dan tepat dosis. Jika salah satu indikator rasionalitas tidak terpenuhi maka hasil analisis ketepatan terapi obat antihipertensi dinyatakan tidak tepat atau tidak rasional. Hasil evaluasi kerasionalan peresepan antihipertensi pada pasien stroke iskemik rawat inap RSUD Dr. Soegiri Lamongan periode Januari-Desember 2018 tersaji dalam Tabel 2 yang menunjukkan penggunaan obat antihipertensi yang rasional sebanyak $91 \%$ sedangkan yang tidak rasional sebanyak $9 \%$. 
Tabel 3. Ketepatan dosis obat antihipertensi pada pasien stroke iskemik rawat inap RSUD Dr. Soegiri Lamongan

\begin{tabular}{lllcc}
\hline No & Obat Antihipertensi & $\begin{array}{l}\text { Dosis } \\
\text { Perhari (mg) }\end{array}$ & $\begin{array}{c}\text { Jumlah } \\
\text { Pasien }\end{array}$ & Ketepatan (\%) \\
\hline 1 & Furosemid & $10-40$ & 11 & 100 \\
2 & Hidroklorotiazid & $12,5-25$ & 1 & 100 \\
3 & Spironolakton & 25 & 9 & 100 \\
4 & Amlodipin & $5-10$ & 82 & 100 \\
5 & Candesartan & $8-16$ & 54 & 100 \\
6 & Lisinopril & $5-10$ & 28 & 100 \\
7 & Bisoprolol & $2,5-5$ & 11 & 100 \\
\hline
\end{tabular}

Sehingga dapat disimpulkan bahwa penggunaan obat antihipertensi lebih banyak yang rasional dibandingkan yang tidak rasional. Penggunaan obat yang rasional diharapkan dapat memberikan outcome klinis berupa tekanan darah dapat terkontrol atau tercapai sesuai dengan target terapi JNC 8.

Tabel 4. Gambaran outcome klinis pada pasien stroke iskemik rawat inap RSUD Dr. Soegiri Lamongan

\begin{tabular}{lcc}
\hline Karakter klinis (tekanan darah) & $\begin{array}{c}\text { Jumlah } \\
\text { Pasien }\end{array}$ & $\%$ \\
\hline Tercapai $<140 / 90 \mathrm{mmHg}$ & 86 & 86 \\
Tidak tercapai $<140 / 90 \mathrm{mmHg}$ & 14 & 14 \\
\hline
\end{tabular}

Hasil penelitian seperti yang dapat dilihat di tabel 4, Pasien yang tidak terkontrol atau tidak tercapai tekanan darahnya sebanyak 14\%. Sedangkan sisanya $86 \%$ pasien mempunyai tekanan darah yang tercapai $<140 / 90 \quad \mathrm{mmHg}$. Menurut Eight Joint National Committee (JNC 8) target tekanan darah pada pasien stroke iskemik dengan hipertensi untuk semua usia yaitu $<140 / 90 \mathrm{mmHg}$. Hal ini menunjukkan bahwa pasien stroke iskemik dengan hipertensi rawat inap di RSUD Dr. Soegiri Lamongan Periode JanuariDesember 2018 lebih banyak pasien yang memiliki tekanan darah terkontrol sesuai dengan JNC 8 dibandingkan yang tidak terkontrol.

Hubungan Kerasionalan Peresepan Antihipertensi dengan Outcome Klinis Analisis hubungan kerasionalan peresepan dengan outcome klinis dilakukan dengan menggunakan metode analisis chi square untuk melihat ada atau tidaknya hubungan kedua variabel tersebut.

Hasil uji statistik yang di tunjukkan nilai expected sebesar 1,26. Syarat analisis person Chi Square Test dapat digunakan jika nilai expected atau expected frequencies $>5$ 
atau maksimal $20 \%$ sehingga analisis chi square test untuk tabel $2 \times 2$ dtersebut harus diganti dengan analisis statistik Fisher's exact test (Dahlan, 2014). Hasil analisis Fisher's exact test dapat dilihat di Tabel 5.

Tabel 5. Analisis statistik Fisher's Exact Test

\begin{tabular}{llllll}
\hline Kerasionalan & \multicolumn{2}{l}{ Outcome Klinis } & Odds & CI 95\% & P \\
\cline { 2 - 3 } & Tercapai & Tidak tercapai & & & \\
\hline Rasional & 81 & 10 & 6,480 & $1,490-$ & 0,021 \\
Tidak Rasional & 5 & 4 & & 28,177 & \\
& & & & &
\end{tabular}

Kerterangan :
CI 95\% $\quad$ : Confidence Interval
$\mathrm{P}$

Hasil analisis dengan menggunakan statistik Fisher's exact test pada Tabel 5 menunjukkan bahwa terapi antihipertensi yang rasional dan mencapai target tekanan darah sebanyak $81 \%$ sedangkan yang rasional dan tidak mencapai target tekanan darah sebanyak $10 \%$. Penggunaan antihipertensi yang tidak rasional dan mencapai tekanan darah sebanyak 5\% sedangkan yang tidak rasional dan tidak mencapai target tekanan darah sebanyak $4 \%$.

Hasil analisis statistik hubungan rasionalitas peresepan obat antihipertensi dengan outcome klinis mempunya nilai signifikasi $0,021<0,05$ menunjukkan bahwa Ha diterima sehingga dapat ditarik kesimpulan bahwa terdapat hubungan antara kerasionalan peresepan antihipertensi pada pasien stroke iskemik dengan outcome klinis. Nilai odds ratio yang diperoleh sebesar 6,480 pada Confidence Interval (95\%) 1,490-28,177 yang artinya pengobatan antihipertensi yang rasional mempunyai peluang 6,480 kali lebih besar untuk mencapai outcome klinis dibanding yang tidak rasional.

\section{KESIMPULAN}

Peresepan antihipertensi pada pasien stroke iskemik rawat inap RSUD Dr. Soegiri Lamongan didominasi oleh golongan CCB yakni amlodipin baik dalam bentuk tunggal maupun kombinasi dengan persentase $41,8 \%$, kerasionalan peresepan mencapat 91 $\%$, outcome klinis tercapai $86 \%$ dan ada hubungan yang signifikan antara kerasionalan peresepan dan outcome klinik.

\section{Daftar Pustaka}

Allihat. 2002. Major outcomes in high-risk hypertensive patients randomized to angiotensincoverting enzym inhibitor, American Medical Association, 288(23):2891-2997

Appleton, J.P., Sprigg, N., Bath, P.M. 2016. Blood pressure management in acute stroke, Stroke and Vasculer Neurology, 1(2): 72-82

Aronow, W.S., Fleg, J.L., Pepine, C.J., Artinian, N.T., Bakris, G., Brown, A.S., Ferdinand, C., Forciea, M.A., Frishman, WH., Jaigobin, C., Kostis, J.B., Mancia, G., Oparil, S., Ortiz, E., Weber, M.A. ACCF/AHA. 2011. expert consensus document on 
hypertension in the elderly. Journal of American Society of Hypertension 2011;5(4): p. 259-352.

Coylewright, M., Reckelhoff, J. F., \& Ouyang, P. 2008. Menopause and hypertension: an ageold debate. Hypertension, 51(4), 952-959.

Dinicolantonio, J. J., Fares, H., Niazi, A. K., Chatterjee, S., Ascenzo, F. D., Cerrato, E., Keefe, J. H. O. 2015. $\beta$-Blockers in hypertension, diabetes, heart failure and acute myocardial infarction : a review of the literature, Open Heart,2: 1-12.

ESC/ESH. 2013. Guideline for the management of arterial hypertension, European Heart Journal, [Online], Sumber: https:/academic.oup.com/eurheartj [Akses: 28 Juni 2019]

Goldstein, L.B., Adams, Robert., Alberts, M.J., Appel, L.J., Brass, L.M., Bushnell, C.D., Culebras, A., DeGraba, T.J., Gorelick, P.B., Guyton, J.R.,hart, R.G., Howard, G., KellyHayes, M., Nixonm, J.V., Sacco, R.L. 2011. Primary Prevention of Ischemic Stroke, Stroke, Vol. 42, p.517-584.

Gormer, B. 2010. Farmakologi hipertensi, diterjemahkan oleh Lyrawati, Diana., 1-7, Jakarta Hankey, G.J. 2003. Angiotensin-converting enzyme inhibitors for stroke prevention is there hope for progress after life, Stroke: 1;34(2):354-6.

JNC 8. 2014. evidance-based guideline for the management of high blood pressure in adult, report from the panel members appointed to the eight Join National Committee (JNC 8) Clinical Review \& Education Special Communication, U.S., Departement of Health and Human Services National Institutes of Health National Heart, Lung, and Blood Institute.

Juan, T., Julian, S., \& Luis, M. 2014. Diuretics in the treatment of hypertension. part 2: loop diuretic and potassium-sparing agent, Sci., 15(5):605-621.

Junaidi, I. 2011. Stroke waspadai ancamannya. Penerbit Andi, Yogyakarta

Kalra, S., Kalra, B., Agrawal, N. 2010. Combination therapy in hypertension: an update. Diabetology and Metabolic Syndrome Journal. India: BioMed Central Ltd. p. 44

Kemenkes RI 2006. Pharmaceutical care untuk penyakit hipertensi, Direktorat Bina Farmasi Komunitas dan Klinik Ditjen Bina Kefarmasian dan Alat Kesehatan, Jakarta.

Kemenkes RI. 2011. Modul penggunaan obat rasional. Kementrian Kesehatan Republik Indonesia, Jakarta

Karuniawati, H., Ikawati, Z., \& Gofir, A. 2015. Pencegahan sekunder untuk menurunkan kejadian stroke berulang pada stroke iskemik. Jurnal Manajemen dan Pelayanan Farmasi, 14, 1421.

Lacy, C., Armstrong, L. L., Lipsy, R. J., \& Lance, L. L. 1993. Drug information handbook 1993. Lexi-comp.

Madscape. 2019. Drug interaction checker, https://reference.medscape.com/druginteractionchecker

Muir, W., and Keith. 2013. Stroke. Medicine, Vol.41 No.3, p. 169-173

Naidu, M.U., Usha, P.R., Rao, T.R., and Shoba, J.C., 2000. Evaluation of amlodipine, lisinopril, and a combination in the treatment of essential hypertension, India: Department of Clinical Pharmacology and Therapeutics, Nizam's Institute of Medical Sciences, Volume 76, p. 350-353.

Nazir, F.S., Overell, J.R, Bolster, A., Hilditch, T.E., Lees, K.R. 2019. Effect of perindopril on 
cerebral and renal perfusion on normotensives in mild early ischaemic stroke: a randomized controlled trial. Cerebrovascular Diseases. 2019;19(2):77-83.

PERDOSSI. 2011. Guideline stroke, Perhimpunan Dokter Spesialis Saraf Indonesia, Jakarta.

Prabhakaran, S. dan Chong, J.Y., 2014, Risk factor management for stroke prevention, Continuum (Minneapolis, Minn. ), 20(2): 296-308.

Ramadhini, A. Z., Angliadi, L. S., \& Angliadi, E. 2013. Gambaran angka kejadian stroke akibat hipertensi di instalasi rehabilitasi medik RSUP Prof. Dr. RD Kandou Manado periode Januari-Desember 2011. e-Clinic, 1(2).

Rashid, P., Leonardi-Bee, J., Bath, P. 2003. Blood pressure reduction and secondary prevention of stroke and other vascular events a systematic review. Stroke. 1;34(11):2741-8.

Ravenni, R. 2011. Primary stroke prevention and hypertension treatment: which is the first-line strategy, Neurol Int., 3(2):12.

Riyadina, W., dan Rahajeng, E. 2013. Determinan penyakit stroke. Kesmas: National Public Health Journal, 7(7), 324-330.

Rossum, V,C.T., van de Mheen, H., Witteman, J. C., Hofman, A., Mackenbach, J. P., \& Grobbee, D. E. 2000. Prevalence, treatment, and control of hypertension by sociodemographic factors among the Dutch elderly. Hypertension, 35(3), 814-821.

Saseen, J.J, and Maclaughlin, E.J. 2008. Hypertension. In: Dipiro, J.T., Talbert, R.L., Yee, G.C., Matzke, G.R., Wells, B.G., Posey, L.M., Pharmacotherapy A Pathopysiologic Approach. 7th edition. The McGraw-Hill Companies, Inc. p. 140-163.

Sedjatiningsih, W. 2013. Pengaruh pemberian obat antihipertensi terhadap penurunan tekanan darah pasien stroke iskemik akut yang menjalani rawat inap di RSUP DR. Sardjito Yogyakarta. Doctoral dissertation. Yogyakarta: Universitas Gadjah Mada.

Sacco, R. L., Kasner, S. E., Broderick, J. P., Caplan, L. R., Connors, J. J., Culebras, A., \& Hoh, B. L. 2013. An updated definition of stroke for the 21st century: a statement for healthcare professionals from the American Heart Association/American Stroke Association. Stroke, 44(7), 2064-2089.

Sumawa, PMR., Adeanne, CW., and Paulina, V.Y.Y. 2015, Evaluasi kerasionalan penggunaan obat antihipertensi pada pasien hipertensi rawat inap di RSUP Prof. Dr. R. D. Kandou Manado Periode Januari-Juni 2014. Sci., 4(3), 2302- 2493.

Tomiyama, H., and Yamashina, A., 2014, Beta-blockers in the management of hypertension and / or chronic kidney disease, Review article, 1-7.

Zhang. 2011. Clinical factors in patients with ischemic versus hemorraghic stroke in East China. World J Emerg Med 2(1):18-23. 